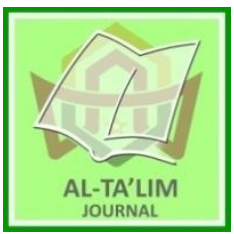

AL-TA'LIM JOURNAL, 26 (3), 2019, (215-224)

(Print ISSN 1410-7546 Online ISSN 2355-7893)

Available online at http://journal.tarbiyahiainib.ac.id/index.php/attalim

\title{
The Competencies of the Islamic Primary Madrasah Student Teachers in Developing K 13-Based Lesson Plan in Aceh
}

Received: $31^{\text {th }}$ April 2019; Revised: $28^{\text {th }}$ May 2019; Accepted: $30^{\text {th }}$ November 2019

Permalink/DOI: http://dx.doi.org/10.15548/jt.v26i3.456

\section{Misbahul Jannah*) \\ Universitas Islam Negeri Ar-Raniry, \\ Banda Aceh, Indonesia \\ E-mail: misbahulj@gmail.com}

\section{Jarjani Usman}

Universitas Islam Negeri Ar-Raniry, Banda Aceh, Indonesia.

E-mail: jarjani@ar-raniry.ac.id

\section{*) Corresponding Author}

\begin{abstract}
This study aims to examine the extent to which the Pendidikan Guru Madrasah Ibtidaiyah (PGMI) or Islamic primary madrasah student teachers have been competent in developing K13based lesson plan. 34 students studying at PGMI Department of the Faculty of Education and Teacher Training of a state Islamic university participated in this study. This research employed qualitative descriptive method. The results show that in general the ability of the student teachers in developing K13-based lesson plan fall into less and good categories. This indicates that the ability of the student teachers has not fully met the process standards of the 2007 regulation no 41 by Ministry of Education and Culture (MOEC). This suggests that the PGMI program make sure that every PGMI student teacher have adequate competencies of developing lesson plan based on K-13 based on the currently implemented approach, such as the scientific approach, and using it in their teaching well.
\end{abstract}

Keywords: Student teacher competency; lesson plan; scientific approach; curriculum implementation; Curriculum 2013

How to Cite: Usman, J., \& Jannah, M. (2020). The competencies of the Islamic primary madrasah student teachers in developing $\mathrm{K}$ 13-based lesson plan in Aceh. Al-Ta Lim Journal, 26(3). doi:http://dx.doi.org/10.15548/jt.v26i3.456

\section{INTRODUCTION}

Indonesia has implemented Curriculum 2013 since 2013 (Hasan, 2013), which was switched from the school-based curriculum, locally called KTSP (Kurikulum Tingkat Satuan Pendidikan). Consequently, teachers at all levels of education need to adapt to the new change, by having competencies to develop and implement the newly implemented curriculum in their teaching and learning process. This is reasonable because their knowledge and ability have a strong impact on their students' academic performance (Bank, 2010; Idrus, 2003; Kusanagi, 2019).

With respect to $\mathrm{K} 13$, teachers need to have knowledge and skills to develop and implement lesson plans using scientific approach for the subjects they teach, by relying on the core competencies (KI) and competency standards (SK) developed by MOEC (MOEC, 2013). Involved in designing process, they are expected to have empirical experiences and right perceptions about the written curriculum products and be able to easily use it at operational level and bring about good student experiences. Teachers' perceptions strongly affect the quality of curriculum implementation (Fullan, 2007, 2015; SLO, 2009).

Why teacher need to learn new knowledge and skills is due to several emphases in $\mathrm{K}-13$, compared to previously implemented curriculum. The first element is its goals, which is to develop productive, 
creative, innovative, and affective Indonesian citizens through nurturing their cognitive, affective and psychomotor domains in integrated ways (MOEC, 2013). The goals of the K-13 are arranged in four core competencies (locally called Kompetensi Inti $=K I)$ that need to be achieved by students, including (1) spiritual competencies, (2) social competencies, (3) knowledge competencies, and (4) skill competencies. Each of the core competencies are broken down into several basic competencies $($ Kompetensi Dasar $=K D)$. From the types of competencies to be achieved, it can be understood that students are expected not only to have knowledge and skills, but also to have spiritual competencies, such to believe in God and practice their religion.

The second important element of K-13 is its emphasis on the use of approach for curriculum development. As stipulated in the regulation, it is necessary for teachers to apply the scientific approach in developing $\mathrm{K}$ 13 lesson plan and implementing it in their teaching and learning process through what is called 5 Ms (MOEC, 2016). The teaching and learning process needs to apply five important activities, including observing (mengamati, $\mathrm{M}_{1}$ ), asking questions (menanya $=\mathrm{M}_{2}$ ), gathering information (mengumpulkan informasi $=\mathrm{M}_{3}$ ), reasoning or analyzing data (menganalisa data $=\mathrm{M}_{4}$ ), and communicating the results (mengomunikasikan hasil $=\mathrm{M}_{5}$ ). Some schools may add two more activities, including creating and networking (MOEC, 2016). Hence, if teacher applies all these activities, students with differences can participate in learning process as all of their domains are involved. However, implementing a new curriculum is not without problems. As has been found in many literatures (Aytan, 2016; Dehghani, Pakmehr, \& Sani, 2011; Lin, Chang, Tsai, \& Kao, 2015; Riley, 2013; Li, Yan, \& Yu, 2014; Mtshali \& Mukamana, 2018; Suyanto, 2017), what has been designed (written curriculum) has complex problems when it is implemented at various educational settings. Some of the problems at implementation level are related the teacher's knowledge and ability to perceive and implement it. This is so because according to Barber and Mourshed (2007), "The quality of an education system cannot exceed the quality of its teachers" (p.16).

Similarly, teachers' lack of competencies also happens in Indonesia in general and in Aceh in particular. As recently reported in many provinces of Indonesia, such in Pontianak (Pontianak post, 2016), Nusa Tenggara Timur (Timor express, 2017), Aceh (Serambi Indonesia, 2018), that the teachers' competencies are low, as indicated in the results of their competency tests, locally called UKG (Ujian Kompetensi Guru) that only 17 percent of them who passed the passing grade 60-100.

The low quality of teachers in Indonesia at all level is of course inseparable from the quality of teacher education which is responsible for preparing future teachers. This is so because teacher education is the venue where teacher identity is constructed. For Islamic primary school in Indonesia's context, for example, PGMI program is in charge to prepare qualified MI teachers. Through the educational programs in teacher education, it is expected to produce MI teacher candidates who have good knowledge, skills and attitudes. One of the teacher educations is the Faculty of Tarbiyah and Teacher Training (FTK) of a state Islamic university (pseudonym is used throughout this article) in Aceh. As future MI teachers, PGMI student teachers are expected to have four main competencies. They are pedagogic competence, personality competence, social competence and professional competence (Hamzah, 2008). These four competencies constitute a unity that describes the PGMI students as potential teachers of MI and professionals who will become classroom teachers. In an effort to improve process and learning outcomes, PGMI students are required to have the ability, one of which is, to develop lesson plans based on K13.

The ability to develop lesson plan is a projection of what is needed in order to achieve a legitimate and valuable goal (Subroto, 2002) and is also necessary for 
targeted learning and learning objectives to be achieved (Ginting, 2008). Lesson is expected to have a high absorptive capacity (applicable) and reflect the level of ability of teachers in carrying out their profession (MOEC, 2013). In short, how the picture of the learning activities that will be carried out in the classroom depends on what teachers have developed in the lesson plan. A wellstructured lesson plan will be meaningless if it is not implemented in earnest and be a guarantee that half of the activities have been successfully implemented (Makruf, 2015).

In $\mathrm{K} 13$, it is imperative that teachers develop lesson plan using the scientific approach (MOEC, 2013). The scientific approach is believed to be a golden bridge in achieving three domains (cognitive, affective and psychomotor) learners. To be able to achieve these three domains, MI student teachers must be able to optimize the professional competence, pedagogy, social and also his personality. Based on the MOEC regulation No. 81A Year 2013, the scientific approach includes observing, asking, trying, associating and communicating. In K13-based lesson plan, observing activities are crucial because it through such activities student teachers provide opportunities for their students to observe learning process through viewing, listening, listening and reading activities. According MOEC (2013), the use of observation in learning process is very useful in encouraging students' curiosity to learn, which in turn create fun and meaningful learning process. Moreover, involved in observation, students will have firsthand experiences and retain their memory. Questioning activity is a good step and can be done by learners (NRC 2000). Questioning is also an important matter in formulating the problem and the question can be answered through a scientific investigation (Harlen, 1996). In K13-based lesson plan, the questioning activities indicate that the prospective teacher gives opportunities for learners to ask questions about what has been observed. Student teachers guide learners to be able to ask productive questions. The question posed is a result of observation of concrete objects to the abstract related facts, concepts, procedures or other things more abstract. Through questioning activities, learners are trained to develop their curiosity.

Further is trying activities, meaning students dig and collect information from various sources through various ways. This activity is done through experiments, reading sources other than textbooks, observing objects and events in everyday life. With respect to this, Susanto (2003) stated that trying activities are useful to show facts, and the relationship between one fact to another or between one variable and another. Associating activities are those that process information that has been collected not only from the results of experimental activities but those of observing activities and information gathering activities. Joyce et al. (2000) state that in this activity, learners' process information about the events they see or experience, prove the nature of objects and conditions, investigate the event of a problem situation. With respect to this, Sardiman (2007) suggests that if teachers can provide good conditions in learning, learners will be motivated in learning, and active in experiencing, finding out and discovering various knowledge in which teacher must guide learners in problem solving.

Communicating activities is the abilities to write and how to write a report, explain the concept, summarize information, process data, use diagrams and create images, models, tables and graphs (National Research Council [NRC], 2000). Communicating activities suggest that the prospective teachers give learners an opportunity to communicate what they have discovered from their experiment. During the activities, learners present the results of observations; make conclusions based on the results of analysis orally, in writing or other media, and respond to the results of other group presentations. It is expected that the application of the five steps of scientific approach in K13-based lesson plan produces professional MI teacher candidates and in accordance with the needs of society in the 21 st century. Several studies have been carried out on the teacher ability to develop lesson plan. It was found that 
teachers' ability in developing lesson plan fall into good category (Galuh, 2016) and low category (Misbahul, 2017; Wati, 2015). Another research on using scientific approach in curriculum development was by Susanto (2018), which focused on exploring the teacher ability to develop Curriculum 2013. He found that the percentage of teachers who were good category in conducting the scientific approach was as follows: (1) observing (M1) was $22.7 \%$, (2) asking questions (M2) 27.8\%, (3) doing experiments (M3) 23.9\%, (4) reasoning (M4) 7.9\%, and (5) communicating (M5) $18 \%$.

Despite these studies, a gap exists in the previous studies. Research by Galuh (2016) focused on the ability of Pedagogic Content Knowledge (PCK) of high school Biology teachers in developing school-based curriculum, whereas research by Misbahul (2016) focused on the ability of early childhood teachers in integrating religious values, social values and scientific values in K13-based lesson plan. Another one, research by Wati (2015) focused on the ability of MI teachers in integrating spiritual and social attitudes in K13-based lesson plan. The research that has been done by the three researchers is on the kindergarten/Islamic kindergarten (RA) teachers, SD/MI, SMA; however, little attention has been given on the ability of PGMI student teachers in developing K13-based lesson plan. Therefore, this study was carried out to fill in the gap by investigating the ability of PGMI student teachers of a state Islamic university in developing K13-based lesson plans.

\section{METHOD}

A Descriptive method was used which aims at descriptively analyzing the ability of the PGMI student teachers in developing K13-based lesson plan by using scientific approach as reflected in the lesson plan. To do so, document analysis and interview were used. Then, interview was used as a complement to find out the students' opinions about their ability. This research was conducted at PGMI program, involving second year students of the Faculty of Tarbiyah and Teacher Training of a state Islamic university in Aceh. In total, 34 PGMI students who had attended the teaching sciences course in academic year 2017/2018 took part in this study. Their ability was measured by analyzing the lesson plan they developed by using the guidelines for analyzing K13-based lesson plan, called Pedoman Analisis RPP K13, that incorporates the steps of the scientific approach, including observing, analyzing, collecting information/ experimenting activities, associating, and communicating (MOEC, 2016). In short, it analyzed the extent to which the steps are reflected in the lesson plan developed by the PGMI student teachers. The results were analyzed by categorizing them into bad, less, good, very good and excellent. Moreover, data were also collected through interviews with the student teachers in order to understand their opinions about the factors that affect their ability.

\section{RESULTS AND DISCUSSION}

The ability of PGMI student teachers in developing K13-based lesson plans was understood by analyzing the lesson plans prepared by students. Four main components were analyzed, including; (1) general criteria; (2) initial activities; (3) core activities and (4) closing activities. The students' ability to do so can be seen in Table 1 below:

Table 1. Total scores and criteria of the ability of MI student teachers in developing K13-based lesson plans

\begin{tabular}{|c|c|c|c|}
\hline No & Component of assessment & Percent & Categories \\
\hline \multicolumn{4}{|c|}{ General criteria } \\
\hline 1 & $\begin{array}{l}\text { Basic competency (Kompetensi Dasar }=K D \text { ) is in line with the learning } \\
\text { materials to be delivered. }\end{array}$ & 76 & Good \\
\hline 2 & The indicator uses operational verbs. & 56 & Less \\
\hline 3 & Learning objectives are formulated based on indicators. & 60 & Good \\
\hline 4 & $\begin{array}{l}\text { Teaching materials are developed based on the formulated learning } \\
\text { objectives. }\end{array}$ & 65 & Good \\
\hline
\end{tabular}




\begin{tabular}{|c|c|c|c|}
\hline No & Component of assessment & Percent & Categories \\
\hline 5 & The sequence of the learning materials is logical. & 70 & Good \\
\hline 6 & The learning method used in accordance with the scientific approach. & 54 & Less \\
\hline \multirow[t]{2}{*}{7} & $\begin{array}{l}\text { Learning media and learning resources are in accordance with the indicators } \\
\text { to be achieved. }\end{array}$ & 58 & Good \\
\hline & Average score & 62.5 & Good \\
\hline \multicolumn{4}{|c|}{ OPENING ACTIVITIES } \\
\hline 8 & Teacher conducts orientation activities (focusing on learners). & 75 & Good \\
\hline 9 & $\begin{array}{l}\text { The teacher does apperception activities related to the material being } \\
\text { learned. }\end{array}$ & 70 & Good \\
\hline 10 & Teacher gives motivation to students. & 50 & Less \\
\hline 11 & Teacher informs the purposes of learning. & 76 & Good \\
\hline & Average score & 67.75 & Good \\
\hline \multicolumn{4}{|c|}{$\begin{array}{l}\text { CORE ACTIVITIES } \\
\text { a. Observing }\end{array}$} \\
\hline 12 & $\begin{array}{l}\text { Teacher invites learners to observe the phenomenon through } \\
\text { video/images/direct observation/other types of media. }\end{array}$ & 66 & Good \\
\hline 13 & The phenomenon observed by learners is contextual. & 58 & Good \\
\hline 14 & $\begin{array}{l}\text { Teacher asks learners to read material through various sources } \\
\text { (internet/books/magazines). }\end{array}$ & 85 & Very good \\
\hline 15 & $\begin{array}{l}\text { The teacher asks the learners to listen to the teacher and friends' } \\
\text { explanations. }\end{array}$ & 59 & Good \\
\hline & Average score & 67 & Good \\
\hline \multicolumn{4}{|c|}{ b. Asking question } \\
\hline 16 & $\begin{array}{l}\text { Teacher encourages learners to ask questions related to observations of what } \\
\text { is seen to be read and heard. }\end{array}$ & 52 & Less \\
\hline 17 & Questions posed by learners are scientific and productive. & 55 & Less \\
\hline & Average score & 53.5 & Less \\
\hline \multicolumn{4}{|c|}{ c. Trying } \\
\hline 18 & Teacher divides groups heterogeneously. & 74 & Good \\
\hline 19 & The teacher divides student working sheets to each group. & 80 & Very good \\
\hline 20 & The teacher shares tools and experimental materials. & 70 & Good \\
\hline 21 & The teacher asks learners to carry out experiment. & 74 & Good \\
\hline & Average score & 74.5 & Good \\
\hline \multicolumn{4}{|c|}{ d. Associating } \\
\hline 22 & $\begin{array}{l}\text { Teacher guides learners to process the information already collected } \\
\text { through experiments into student working sheets. }\end{array}$ & 54 & Less \\
\hline \multirow[t]{2}{*}{23} & $\begin{array}{l}\text { The teacher asks learners to review the explanation that has been made and } \\
\text { analyze the explanation. }\end{array}$ & 52 & Less \\
\hline & Average score & 53 & Less \\
\hline \multicolumn{4}{|c|}{ e. Communicating } \\
\hline 24 & $\begin{array}{l}\text { Teacher provides opportunities for learners to communicate what they have } \\
\text { learned or concluded verbally, in writing, or with other types of media. }\end{array}$ & 75 & Good \\
\hline 25 & $\begin{array}{l}\text { The teacher gives each group a chance to respond to the results of other } \\
\text { group presentations }\end{array}$ & 55 & Less \\
\hline \multirow[t]{3}{*}{26} & Teacher provides reinforcement of group work & 62 & Good \\
\hline & Average score & 64 & Good \\
\hline & Average score of core activities & 62.4 & Good \\
\hline \multicolumn{4}{|c|}{ CLOSING ACTIVITIES } \\
\hline 27 & Teacher reflects on learning by involving learners. & 70 & Good \\
\hline 28 & Teacher provides opportunities for learners to deduce learning materials. & 72 & Good \\
\hline \multirow[t]{2}{*}{29} & Teacher reinforces the conclusions of learners. & 50 & Less \\
\hline & Average score & 64 & Good \\
\hline \multicolumn{4}{|c|}{ EVALUATION } \\
\hline 30 & Assessment of attitudes is accordance with the indicators. & 54 & Less \\
\hline 31 & Assessment of knowledge is in accordance with the indicators. & 68 & Good \\
\hline 32 & Assessment of skills is accordance with the indicators. & 50 & Less \\
\hline 33 & $\begin{array}{l}\text { Evaluation instruments are complete (guidelines / questions, keys, scores). } \\
\text { Average score }\end{array}$ & $\begin{array}{c}55 \\
56.75\end{array}$ & $\begin{array}{l}\text { Less } \\
\text { Less }\end{array}$ \\
\hline
\end{tabular}

Source: MOEC (2013). 
Table 1 above shows that, in general, the ability of MI student teachers assessed on the four major components falls into less and good categories. The average percentage of good category on general criteria component was $62.5 \%$, initial activities $67.75 \%$, core activities $62.4 \%$ and closing activities $64 \%$, whereas the percentage of the assessment component averagely falls into less category $(56.75 \%)$.

However, of the seven aspects assessed in the general criteria component, there are two aspects that fall into less category, namely the aspects of the indicators using operational verbs, or locally called $\mathrm{KKO}=$ Kata Kerja Operasional), and aspects of learning methods used in accordance with K13 (scientific approach). The other five aspects are into good category. The five aspects are basic competencies in accordance with the materials that will be delivered, the learning objectives formulated based on the indicators, the teaching materials are based on the formulated learning objectives, the sequence of logical learning materials and media and learning resources are in accordance with the indicators to be achieved.

Based on interviews with some students, the lack of their ability to use operational verbs in the indicators was because the lecturer did not explain in detail about the Bloom Taxonomy stages, in the aspects of knowledge, attitudes to skills. Lecturers briefly exposed about the operational verbs. When developing the lesson plan, the PGMI student teachers were not guided in determining appropriate operational verbs in the indicators, so that the formulated indicators are observable and measureable in terms of knowledge, attitude and skills. The regulation of MOEC no 22 in 2016 on Process Standards stipulates that indicators of achievement of competencies should be formulated by using operational verbs that are observable and measureable in three aspects including knowledge, attitudes and skills (MOEC, 2016).

Furthermore, the results of the interviews also show that the PGMI student teachers were still confused in determining the learning methods used in accordance with K13 (scientific approach). Lecturers did not guide the PGMI student teachers in determining the method of learning, making them unable to fulfill the standard provisions of the process of choosing methods in accordance with the characteristics of each indicator, the situation and condition of learners and meaningful learning experience. With respect to this, the regulation of MOEC No 41 in 2007 on Process Standards stipulates that the selection of learning methods should be tailored to the situation and condition of learners as well as the characteristics of each indicator and the competence to be achieved on each subject (MOEC, 2016). Thus, the selection of appropriate learning methods can create a fun learning atmosphere and learners can achieve the indicator set.

In the initial activity component, from the four aspects observed, only one aspect falls into the less category i.e. the aspect of the teacher providing the motivation. The other three aspects fall into the good category in terms of teachers doing orientation activities (focusing learners), teachers doing apperception activities related to the material being learnt and the teacher explaining the purpose of learning. Generating learning motivation learners is the motor of learning activities and related to the learning objectives to be achieved. The low ability of PGMI student teachers in providing motivation also has an impact on the motivation of students. Therefore, PGMI student teachers should motivate learners to learn in the beginning of learning so that learning becomes effective and fun and the expected goals are achieved.

Table 1 also shows that in the core activity component, of the five steps of the scientific approach observed, two steps fall into the less category of questioning and associating, whereas the other three steps are in the good category of observing, trying and communicating. The ability of the student teachers in questioning fall into less category because they have not had experiences of asking using scientific and productive questions in K13-based lesson plans. They have no experience in developing K13-based 
lesson plan that requires students to ask questions with scientific and productive questions. Asking questions is a basic ability to teach teachers to develop learners' activities in a K13-based lesson plan. This ability is also the main thing teacher needs to have if they want to develop scientific knowledge and understanding. With regard to this, NRC (2000) notes that asking question is a good step and can be done by learners. Meanwhile, according to Harlen (1996), asking question is an important thing in formulating the problem, and the question can be answered through scientific investigation.

Furthermore, the step that is in the less category on the core activities is to associate. In the compiled lesson plans, prospective MI teacher less students can guide learners to process the information that has been collected through experiments into the student worksheets. Students of MI teacher candidates also after conducting experiments do not instruct learners to re-analyze the explanations that have been made. In this regard, Sardiman (2007) argued that if teachers can provide good conditions in learning then learners can be motivated in learning, so that learners will be active in experiencing, finding and finding the various knowledge needed and of course the teacher must guide the learners in finding the problem.

In the final stage activities, only one aspect falls in the less category, that is the aspect of the teacher making conclusions. The other two aspects are in the good category, including the aspect of the teacher doing reflection of the teaching and learning process by involving learners, and that of teachers providing opportunities for learners to make conclusions of the learning materials. The lack of ability of the student teachers in giving reinforcement to the conclusions is caused by they had yet mastered the learning materials.

In the last component of assessment, of the four aspects observed, all aspects fall into less category. The lack of ability of the student teachers in the assessment component of lesson plan is due to the lack of ability to use operational verbs in the indicators; accordingly, the formulated indicators cannot be observed and measured in terms of knowledge, attitude and skills. Thus, it can be understood that an important component in the lesson plan is an indicator of the achieving the competencies. The importance of indicators as it becomes the basis for formulating assessment indicators. The formulation of the assessment indicator can be developed into an assessment instrument of knowledge, attitude and skills both in the form of test questions, observation, product assessment (the work of learners), selfassessment and rubric. In addition, the lack of ability of PGMI student teachers in the assessment component in the lesson is also due to their lack of knowledge in the course of learning evaluation. This is as stated by Misbahul (2016) that the forms and types of instruments and procedures developed by lecturers in conducting the evaluation will be a model for prospective teachers to improve their ability in evaluation. Therefore, the performance of IPA lecturers in evaluating contributes also to the evaluation ability of PGMI student teachers. The results of the data analysis above show that PGMI student teachers have not been fully able to develop lesson plan based on K13. The finding is consistent with Misbahul's (2017) and Wati's (2015) research findings. This incapacity is caused by the PGMI students as MI teacher candidate not fully understand lesson plan K13 by using scientific approach. The integration of scientific approach in lesson plan by PGMI student teachers is very important, because if the lesson plan is made well then the implementation of learning will also be good. On the contrary if the lesson plan has been well prepared but not well implemented in class then the expected result is not satisfactory. This is in line with what Makruf (2015) says that a well-planned program will guide the program implementer (teacher) in performing better guidance. But a well-crafted program plan will be worth nothing if it is not done in earnest. Furthermore, Makruf added that a wellstructured lesson plan is a guarantee that half of the activities have been successfully implemented. Conversely, educators fail to 
plan as well as planning for failure. Therefore, the KDP-based lesson plan is expected to have a high absorptive capacity and can know the level of ability of teachers in carrying out their profession.

\section{CONCLUSIONS AND RECOMMENDATION}

After having analyzed the data and discussed the findings, this study concludes that the competencies of the PGMI student teachers in developing lesson plan based on $\mathrm{K} 13$ in the three components (general criteria components, initial, core and closing activities) fall into good category in all activities. Differently, their competencies in assessment component are in less category. This suggests that the ability of PGMI student teachers in developing K13-based lesson plan has not fully complied with the regulation of MONE no 41 of 2007 on Process Standards (MOEC, 2016).

Therefore, it is crucial that the PGMI study program provides enough opportunities and creative ways for PGMI student teachers to develop lesson plan based on K13 that integrates the scientific approach steps. In that way, student teachers will be able to develop it professionally and use it in teaching and learning process. Therefore, further research is needed in the stages of concerns of each individual student teacher on lesson plan development and their level of use. In this way, every problem an individual has can be detected for improvement.

\section{REFERENCES}

Aytan, T. (2016). Evaluation of the 2006 and 2015 Turkish education program in secondary school curriculum in Turkey in terms of critical thinking. Journal of Education and Learning, $5(2)$, $38-46$. https://doi.org/10.5539/jel.v5n2p38

Barber, M., \& Mourshed, M. (2007). How the world's best performing schools come out on top. New York: McKinsey \& Company.
Bowen, G. A. (2009). Document analysis as a qualitative research method. Qualitative Research Journal, 9(2), 27-40. DOI 10.3316/QRJ0902027.

Corbin, J. \& Strauss, A. (2008). Basics of qualitative research: Techniques and procedures for developing grounded theory ( $3^{\text {rd }}$ ed.). Thousand Oaks, CA: Sage.

Dehghani, M., Pakmehr, H., \& Sani, H.J. (2011). Managerial Challenges of Curriculum Implementation in Higher Education. Procedia - Social and Behavioral Sciences, 15, 2003-2006.

Fullan, M. (2007). The new meaning of educational change. ( $\left.4^{\text {th }} e d.\right)$. New York: Teachers College Press.

Fullan, M. (2015). The new meaning of educational change. ( $5^{\text {th }}$ ed.). New York: Teachers College Press.

Ginting, A. (2008). Belajar dan pembelajaran. Bandung: Humaniora.

Hamzah, U. (2008). Orientasi baru dalam psikologi pembelajaran. Jakarta: Bumi Aksara.

Harlen, W., Holroyd, C. \& Byrne, M. (1996). Confidence and understanding in teaching science and technology in primary schools. Edinburgh: Scottish Council for Research in Education.

Hasan, S.H. (2013). History education in curriculum 2013: A new approach to teaching history. Historia: International Journal of History Education, 15(2), 163-178.

Hopkins, W.G. (2008). Quantitative research design. Sportscience, 1(4),

Idrus, N. (2003). Transforming quality for development. Quality in Higher Education, 9(2), 141-150.

Joyce, B., Weil, M., \& Calhoun, E. (2000). Models of teaching ( $6^{\text {th }}$ ed.). Boston: Allyn and Bacon. 
Kusanagi, K. N. (2019). Transformation of Lesson Study in Indonesia: From Government-Assisted Projects to Professional Learning Communities. Tokkatsu: The Japanese Educational Model Of Holistic Education, 259.

Lin, K., Chang, L., Tsai, F., \& Kao, C. (2015). Examining the gaps between teaching and learning in the technology curriculum within Taiwan's 9-year articulated curriculum reform from the perspective of curriculum implementation. International Journal of Technology and Design Education, 25(3), 363385 .

Makruf, I. (2015). Modul 7 guru kelas Raudhatul Athfal. Pengembangan perangkat pembelajaran untuk $R A$. Jakarta: UIN Syarif Hidayatullah.

Ministry of Education and Culture [MOEC]. (2013). Buku diklat guru dalam rangka implementasi Kurikulum 2013, mata diklat: 2. Analisis materi ajar, jenjang: $\quad$ SD/SMP/SMA, Mata pelajaran: Konsep pendekatan scientific. Jakarta: Kemendikbud.

Misbahul, J. (2016). Kemampuan mahasiswa calon guru madrasah ibtidaiyah (MI) dalam evaluasi pembelajaran IPA. The $1^{\text {st }}$ Ar-Raniry International Conference on Islamic Studies (ARICIS) UIN ArRaniry Darussalam Vol 1 hal: 109118.

Misbahul, J. (2017). Kemampuan guru PAUD dalam mengintegrasikan nilai pada rencana pembelajaran harian (RPPH) anak usia dini di Kabupaten Pidie Jaya. Jurnal PSGA Edisi Jan-Jun 2017.

MOEC. (2013). Peraturan Menteri Pendidikan dan Kebudayaan Republik Indonesia nomor 81a tahun 2013 tentang implementasi kurikulum.

MOEC. (2016). Peraturan Menteri Pendidikan dan Kebudayaan nomor
22 tahun 2016 tentang standar proses pendidikan dasar dan menengah.

Muhammad, N.H. (2006). Quality education needs quality teachers: Our education our thoughts. Campaign for Popular Education Bangladesh.

Muraraneza, C., \& Mtshali, G.N. (2018). Implementation of competency based curriculum in pre-service nursing education: Middle range theory. International Journal of Africa Nursing Sciences, 8, 53-58.

National Research Council (NRC). (2000). Inquiry and the national science education standards: A guide for teaching and learning. Washington, DC: National Academy Press.

Rapley, T. (2007). Doing conversation, discourse and document analysis. London: Sage.

Sardiman, A. (2007). Interaksi dan motivasi belajar. Jakarta: Raja Grafindo Persada.

Serambi Indonesia. (2018, January 01). Gurutak-lulus-UKG-tidak-dipecat.

SLO (Netherlands Institute for Curriculum Development). (2009). Curriculum in development. Enschede: SLO.

Subroto, S. (2002). Proses belajar mengajar di sekolah. Jakarta: Rineka Cipta.

Susanto, P. (2003). Kemahiran dasar mengajar IPA berbasis kontruktivisme. Malang: Universitas Negeri Malang.

Suyanto, S. (2017). A reflection on the implementation of a new curriculum in Indonesia: A crucial problem on school readiness. Proceeding of the 4th International Conference on Research, Implementation, and Education of Mathematics and Science (4th ICRIEMS): Research and Education for Developing Scientific Attitude in Sciences and Mathematics. 
Yogyakarta: Universitas Negeri Yogyakarta.

Suyanto, S. (2018). The Implementation of the scientific approach through $5 \mathrm{Ms}$ of the new curriculum of 2013 in Indonesia. Jurnal Cakrawala Pendidikan, 1, 19-28.

Toharuddin, U. (2005). Kompetensi guru dalam strategi ajar.

Wati, O. (2015). Kemampuan guru dalam mengintegrasikan sikap spiritual dan sosial dalam pembelajaran berbasis Kurikulum 2013 pada MIN mitra FTK UIN Ar-Raniry. Laporan Penelitian. Banda Aceh: UIN Ar-Raniry.

Bank, W. (2010). Transforming Indonesia's Teaching Force. Volume II: From PreService Training to Retirement: Producing and Maintaining a HighQuality, Efficient, and Motivated Workforce. 